\section{Science spending still in vogue}

FrENCH scientists are to benefit again from the strong political support given to research in France since the present socialist government came to power in 1981 - but some will benefit a good deal more than others. That is the message of the 1986 government budget announced by Prime Minister Laurent Fabius late last month, a budget in which real civil research funding will rise by around 8 per cent, while the total government budget will remain constant or even decrease. The government's target of 3 per cent of gross national product (GNP) for the national research and development budget will be reached "without doubt" by the end of the decade, research minister Hubert Curien has buoyantly predicted. The present figure is 2.3 per cent, and Curien predicts an increase to 2.4 per cent next year.

However, these and similar figures in the past, have hidden a number of hard truths. On the whole, basic research has fared less well politically than applied, but in applied sciences the new spending has not always been well-conceived; and a considerable fall in the value of the franc over recent years has increased the real cost in France of many research materials and equipment, most of which have to be bought outside in hard-currency countries such as the United States, West Germany and Switzerland. Molecular biologists, in particular, even those in leading laboratories, consider that their budgets have only kept pace with the rising costs of research. "But that's better than many of our colleagues abroad", said one.

Nevertheless, 1986 may be different. Curien has taken on board the need for the "re-equipment" of many French laboratories and set aside a special budget for the purpose. At the Centre National de la Recherche Scientifique (CNRS) France's leading basic research council for example, next year's spending will include a 25 per cent increase in the budget for "medium heavy equipment", CNRS director Pierre Papon promises. "This means things like nuclear magnetic resonance spectrometers, infrared spectrometers and minicomputers, things costing FF $1-2$ million $(£ 100,000-200,000) "$, said

\title{
Europe jostles for position in high-tech
}

\section{Brussels}

As part of a campaign to convince EEC foreign ministers of the important role that the European Community could play in promoting Europe's high technology, president of the European Commission, M. Jacques Delors, last week gave EEC foreign ministers their first look at the Community's new research and development "framework programme" for the years 1987 to 1991 .

The new programme, intended to exploit the impetus given to technological cooperation by the French-inspired Eureka project, aims at striking a "new balance involving new topics". The areas covered include:

- The exploitation of space, mainly through remote sensing of resources and land-use in Europe and developing countries. This would involve setting up a usernetwork and some Earth stations, and would complement the facilities of the European Space Agency.

- The development of new energyconserving and environmentally sound means of marine transport.

- The use of information and telecommunications technology to improve road transport in Europe.

- An as yet undefined project in aviation.

- The development of low cost educational tools for distance teaching (the Delta project).

- Improved research grants and social legislation to promote the mobility of research workers in the Community.
For most of these proposals, Delors hopes to have detailed plans worked out before the end of 1986 .

As well as instituting new projects, the Commission is planning to speed up and extend existing EEC programmes. As a first step, the Esprit high-technology research programme should move into its next phase, involving demonstration and target-oriented projects. The recently relaunched medical research programme should include research on AIDS (acquired immune deficiency syndrome) and a cancer coordination project. And the biotechnology programme should be applying the new techniques to the problems of agriculture.

M. Delors sees room for, in the current EEC jargon, both "joint action" and "variable geometry". An example of the latter is the Eureka programme, which is basically a French initiative. The foreign ministers of the smaller EEC states (Netherlands, Belgium, Luxembourg and Ireland) have told M. Delors that they fear projects such as Eureka could leave them out in the cold, with the larger countries dividing the spoils between themselves. These smaller states are looking to the Commission to defend their interests and to become a focal point for future development of Eureka.

EEC research ministers will take up some of these points in an informal meeting on 23 October in the run up to the next Eureka interministerial conference, to be held in Hannover on 5 November.

Anna Lubinska
Papon. CNRS spent FF 100 million ( $£ 10$ million) on such items last year, and will spend FF 125 million in 1986. Materials science, robotics, electronics and chemistry may see the greatest benefit.

Altogether, the CNRS spending authorizations will increase by 8.4 per cent in current francs against a predicted 3.6 per cent inflation. This is "a very useful and very important increase", says Papon, which will be distributed in line with the CNRS 7-year strategic plan prepared earlier this year (see Nature 315, 5; 1985). Life sciences "which have been a priority for 3 or 4 years" will see "a specific effort in general support for laboratory metarials", but in recent months the franc has improved against the dollar, easing the problem in this area, said Papon. Engineering and social sciences will also receive special attention.

CNRS also plans to spend more on valorization - the process of making CNRS research profitable through links with industry, patenting and other measures - and to increase the budget of the international affairs division "especially for European cooperation". This may take the form of more exchange agreements, perhaps with Austria and Switzerland (where Papon is hoping to forge strong links), to complete agreements CNRS has now made "with every country in Western Europe".

There will also be more jobs at CNRS - another 300 for scientists and engineers in 1986. And Curien's ministry of research is aiming at the high target of 5 per cent annual scientific recruitment (as a proportion of present staff), to compensate for retirements and transfers. The immobility of French scientists, who rarely even stray from their home town, is still taxing the minister, however

Other points in the budget include: - Spending on the Agence Française pour la Maitrise de l'Energie (AFME), the French council for the support of initiatives in energy conservation and renewable resources, is to fall 3.7 per cent in current francs (some 7 per cent in real terms), reflecting a French energy glut due to nuclear power, and less pressure on national income due to lower oil prices.

- The medical research council INSERM will receive an 8.9 per cent increase (a little more than CNRS). The agricultural research council INRA is to get an 8.2 per cent increase.

- The budget of the space research council CNES, now developing the next, fully cryogenic version of the Ariane launcher, will be lifted another 23 per cent.

- Funds for developing French capability in electronics will also rise by nearly a quarter (23.8 per cent)

- The six biggest spenders in 1986 will be: CNRS (FF 8,951 million); Commissariat à l'Energie Atomique (CEA) (FF 7,044 million); CNES (FF 4,210 million); INRA (FF 2,233 million); and INSERM (FF 1,621 million).

Robert Walgate 